\title{
Barreiras às TVs educativas e culturais no Brasil
}

Mônica Bernardo Schettini Marques

\section{Resumo}

No presente artigo, procuramos examinar os problemas que afetam as emissoras de TV brasileiras de caráter educativo e cultural, muitas delas designadas como TVs públicas ${ }^{1}$. Procuramos averiguar as barreiras enfrentadas por este tipo de empreendimento, tanto no que diz respeito à conquista de um público mais amplo, quanto naquilo que se refere à forma e ao conteúdo transmitido. Nossa hipótese é a de que a formação escolar precária da maior parte da população do país e a falta de acesso da mesma a museus, cinemas, teatros, bibliotecas, entre outros, são fatores centrais que acabam por intimidar o receptor quando este se vê diante dos programas de conteúdo educativo e/ou cultural.

Palauras-chave:

TV pública, Escolaridade, Recepção

\section{Barriers to educational and cultural TV in Brazil}

\section{Abstract}

In the present article, we try to examine the problems that affect the Brazilian broadcast stations characterized by an education and cultural approach, many of them called public $\mathrm{TVs}^{1}$. We try to evaluate the barriers that this kind of enterprise has to face, in respect to the conquest of a wider public, and to what concerns the shape and the content that are transmitted. Our main hypotheses is that the deficient educational background of the majority of the people and the lack of access to museums, cinemas, theaters, libraries, among others, are central factors that intimidate the receptor when he is confronted with programs of remarkable educational and cultural content.

Sobre a autora Doutora em Comunicação e Semiótica pela PUC-SP, professora do Curso de Comunicação Social da Uniesp. monicaschettini@uol.com.br
Key words:

Public TV, Educational level, Reception 


\section{As TVs educativas e culturais e seu contexto}

Os descaminhos das TVs brasileiras de caráter educativo e cultural estão, em nossa perspectiva, associados à formação escolar precária de boa parte da população. Antes de apresentarmos nossa reflexão sobre o tema, parece-nos pertinente uma breve mirada sobre algumas das recentes pesquisas que procuram averiguar o desempenho escolar dos estudantes e o nível de escolaridade dos docentes.

O cenário, que as avaliações com alunos e professores da rede pública expõem, é desanimador. Conforme informa reportagem da Folha de S. Paulo ${ }^{2}$, os resultados do último Saeb, exame federal de avaliação de aprendizagem, referentes ao Estado de São Paulo, mostram que 43,1\% dos alunos do terceiro ano do ensino médio (antigo colegial) tiveram em conhecimentos relativos à escrita e à leitura notas inferiores a 250, patamar fixado como o mínimo para a oitava série, pela secretária de Estado de Educação, Maria Helena Guimarães de Castro ${ }^{3}$. Esses números englobam os resultados obtidos nas avaliações de estudantes das redes pública e privada, mas poderiam ser ainda mais dramáticos, caso auferissem apenas os dados da primeira, uma vez que esses são $21 \%$ inferiores à média obtida pelos alunos das instituições particulares. As más condições de trabalho dos professores, entre elas, baixos salários e extensa jornada, estão entre os diversos fatores mencionados por especialistas para tentar explicar o quadro. Deve-se, ainda, ter em vista que a própria qualificação dos docentes é precária. Como enfatiza outra reportagem ${ }^{4}$, publicada no mesmo jornal, 47\% daqueles que lecionam na pré-escola e no primeiro ciclo não têm diploma universitário.

O resultado do último Pisa, Programa Internacional de Avaliação de Alunos, aplicado pela OCDE (Organização para a Cooperação e Desenvolvimento Econômico), reitera esse quadro. No exame, que em 2006 comparou o desempenho de alunos de dezenas de países, o Brasil alcançou $52^{\mathrm{a}}$ posição na área de ciências (entre 57 nações), a $53^{\mathrm{a}}$ em matemática (entre 57) e a $48^{\mathrm{a}}$ em leitura (entre 56) .

A precariedade da educação no país não nos parece um fator coadjuvante ou inexpressivo para a discussão das TVs educativas e culturais. Muito pelo contrário. Nossa hipótese é a de que a não exposição anterior a certos conteúdos, ou experiências frustrantes relativas às ciências, à literatura, ao cinema, à língua portuguesa, podem intimidar ou provocar o desinteresse do receptor diante de programas que abordem esses temas e que, muitas vezes, tentam minimizar as deficiências oriundas justamente da formação escolar insuficiente, ou da notável falta de acesso da população brasileira aos bens culturais. A quase ausência destes parece ser mais um empecilho para o pleno desenvolvimento de uma TV de qualidade no país.
${ }^{1}$ Laurindo Lalo Leal Filho esclarece em entrevista concedida ao jornal Brasil de Fato como se configuraria uma TV pública. Nas palavras do pesquisador: "É aquela gerida por organizações e conselhos formados pela própria sociedade e não podem ter ingerência da publicidade e nem do Estado. Esse modelo deve ter uma autonomia em relação ao Estado e à iniciativa privada. Na Europa, talvez o modelo mais bem acabado é a BBC. Ela é mantida pela própria população. Todos que possuem uma TV em casa pagam uma cota anual, obrigatória, e é esse dinheiro que a mantém. Seu controle é exercido por um conselho curador eleito e indicado por organizações sociais e, depois, aprovado pelo Parlamento [...]". "Aqui, talvez a que mais se aproxime da BBC seja a Fundação Padre Anchieta que mantém a Rádio e TV Cultura, no Estado de São Paulo. Ela foi criada como uma fundação de direito privado. Essa implicação legal faz com que o Estado não tenha poder para intervir sobre ela. Institucionalmente, não tem nenhum vínculo com o Estado. O conselho curador, como na BBC, é o órgão máximo e é quem elege a diretoria e dá - ou deveria dar - a linha editorial. Há também a Fundação Piratini, mantenedora das emissoras de TV e rádio educativa do Rio Grande do Sul, e a TV Ponta Grossa, uma emissora de direito privado, ligada ao município. Agora, na prática, essa independência acaba não acontecendo, porque o poder público é geralmente o principal -e às vezes único - financiador da emissora, e impõe certas condições: manobra as eleições dos dirigentes, consegue estabelecer maiorias nos conselhos, enfim, interfere e faz com que essas emissoras deixem de ser públicas e se 
$\mathrm{O}$ raciocínio é semelhante àquele que operamos em relação à formação escolar. Se o indivíduo vive em uma cidade em que não há museus, livrarias, salas de concertos, teatros e se ainda tem uma formação escolar insuficiente, a programação da TV pública pode lhe parecer desinteressante ou intimidadora. Não é possível pensar a relação do espectador com uma TV que pretenda educar, informar e ao mesmo tempo entreter, desvinculando-a do contexto social, do espaço em que se vive, da infra-estrutura que esse ambiente dispõe e das relações que nele se estabelecem. Assistir à TV é uma ação que joga necessariamente com as forças sociais e com as outras formas de acesso à cultura e à educação disponíveis ao indivíduo em seu meio.

Como nos informa Wolf (1999: 37), já nos anos 40, pesquisas relacionadas ao comportamento das audiências detectavam:

[...] se aqueles que manifestam interesse por determinado assunto, o fazem depois de a ele terem sido expostos, aqueles que se mostram desinteressados e desinformados fazem-no porque nunca foram expostos à informação referente a esse mesmo assunto.

A conclusão de abordagens experimentais de tantas décadas anteriores parece-nos ainda válida para refletir sobre a relação do espectador brasileiro com a TV.

Nesse cenário, talvez seja o caso de repensarmos a declaração de Rocco (2000), quando a autora se refere aos argumentos que justificam a programação de baixa qualidade da TV:

Se há um processo de exclusão, a exclusão da escola, dos bens de consumo, dos teatros, a maior exclusão possível que alguém pode cometer é considerar que pessoas pouco dotadas financeiramente e socialmente não têm prazer com um produto de boa qualidade.

A ausência de prazer com uma programação de qualidade está, em nossa perspectiva, associada a todas aquelas exclusões e a sua constatação, por si só, não nos parece um mecanismo de exclusão. Mas esta ausência não pode ser justificativa para uma programação destituída de qualidade. Por outro lado, a qualidade da programação da TV brasileira e, especialmente, a qualidade da programação das TVs públicas, não pode ser também, em nossa perspectiva, pensada separadamente da quantidade de pessoas que se deseja atingir.

Uma emissora que se diz pública deve chegar ao público. Não ter essa meta em vista seria contraditório com o empreendimento. Não se pode, contudo, abandonar o compromisso com a qualidade da programação, visar uma audiência global, pura e simplesmente, deixar que o índice de audiência, por si só, reja a programação. É preciso sempre tentar o encaixe, por vezes difícil, entre qualidade e audiência. tornem quase estatais, ou totalmente estatais".

Em nossa reflexão não nos deteremos exclusivamente nas redes nacionais, consideradas por Leal, mais próximas ao modelo público britânico. Procuraremos, na realidade, examinar os obstáculos que perpassam todas aquelas TVs que tenham como marca a transmissão de um conteúdo educativo e cultural e não estejam vinculadas a uma rede comercial, uma vez que neste último caso os problemas relativos ao financiamento, aqui destacados, merecem uma abordagem específica. Nossa reflexão concentra-se, assim, nas emissoras de caráter educativo e cultural, sejam elas geridas por um conselho, como é o caso da TV Cultura, por universidades, ou pelo Estado (Leal, 2007.)

2 Takahashi, Fábio. Alunos do $3^{\circ}$ ano têm nota de $8^{a}$ série. Folha de S. Paulo, São Paulo, 1 out. 2007. Cotidiano, p. 1.

${ }^{3}$ De acordo com a reportagem, a secretária de Estado de Educação, Maria Helena Guimarães de Castro, que presidiu o Inep (Instituto Nacional de Estudos e Pesquisas Educacionais), onde ajudou a implantar o Saeb, fixou como patamares mínimos para língua portuguesa a nota 200, para a quarta série (escala até 350); 250 para a oitava (escala até 375$)$ e 300 para o ensino médio (escala até 425). A direção atual do instituto alega, entretanto, que não há consenso entre os educadores sobre os níveis fixados como mínimos.

${ }^{4}$ Góis, Antônio. 47\% dos professores até a $4^{\mathrm{a}}$ série não têm diploma universitário. Folha de $S$. Paulo, São Paulo, 22 out. 2007. Cotidiano, p.5.2007. 


\section{A necessidade de uma TV de qualidade no Brasil}

Uma realidade marcada pela precariedade dos estabelecimentos de ensino, pela baixa oferta de bens culturais e pela presença obrigatória da televisão em quase que a totalidade dos domicílios do país nos faz atentar para a importância que este meio de comunicação tem na formação dos brasileiros e para a necessidade de uma programação de qualidade.

Como nos lembra Bourdieu (1997: 23), "há uma proporção de pessoas muito grande que não lêem nenhum jornal, que estão voltadas de corpo e alma à televisão como única fonte de informações”. A situação detectada pelo sociólogo parece ser muito mais grave no Brasil, se pensarmos que o autor tem em vista o cenário europeu, principalmente. Os índices de aproveitamento escolar, arrolados no início deste artigo, mostram a precariedade da capacidade de leitura dos brasileiros que estão em processo de formação. Quando a televisão é a principal, senão a única fonte de acesso de boa parte do público à informação, como percebe o autor, "o meio acaba por ter uma espécie de monopólio de fato sobre as cabeças de uma parcela importante da população" (ibid.: 22). Assim, ao consumir o tempo dos espectadores com variedades, programas sensacionalistas, a TV acaba por afastálos "das informações pertinentes que deveria possuir o cidadão para exercer seus direitos democráticos" (ibid.:, 24).

O Brasil não é o único país do mundo brindado com uma programação televisiva de baixíssima qualidade. Reportagens sensacionalistas, programas de auditório, também existem na França, Espanha e Itália, como destaca Carvalho (2000: 307). Mas, como adverte o autor, quando se pensa em TV no Brasil, é preciso ter em vista que essa é uma das poucas opções de lazer da população. Cinema e teatro tornam-se programas inviáveis, considerando-se a baixa renda da maior parte da população. Deve-se levar em conta ainda que a violência das grandes cidades acaba afugentando a população desse tipo de lazer.

Quando o acesso da população a outras fontes de informação, cultura e lazer é precário, a necessidade de uma TV de qualidade é urgente.

\section{A prevalência do modelo de TV comercial no país}

A adoção no Brasil do modelo de TV comercial desde o início da história do meio no país, num percurso diverso daquele percorrido pelas nações européias, favoreceu o desenvolvimento da atividade publicitária e a competição desigual entre TVs educativas e estatais, que recebiam uma verba muitas vezes insuficiente do governo, e TVs comerciais, que encontravam nos anunciantes o caminho para a lucratividade, para a formação de uma estrutura tecnológica avançada e para a catalisação de técnicos e criadores. Como concentrar os principais criadores do país, se a oferta da

A baixa oferta de
bens culturais e a
presença obrigatória
da televisão em
quase toda a
totalidade dos
domicílios do país
faz atentar para a
necessidade de uma
programação de
qualidade

A baixa oferta de bens culturais e a presença obrigatória da televisão em quase toda a totalidade dos domicílios do país necessidade de uma qualidade 
emissora comercial concorrente é mais vantajosa? Não podemos nos esquecer que a televisão é um meio de comunicação que envolve altos custos de produção.

A situação enfrentada pela TV Cultura exemplifica o problema. Embora tenham surgido bons programas nas décadas de 70, 80 e no início dos anos 90, com os cortes de orçamento decorrentes do processo de liberalização da economia, a emissora passou a reprisar programas e a audiência caiu.

É preciso notar ainda que a prevalência da TV comercial no país acaba por criar na mente do espectador um modelo ideal de programação, deixando poucas brechas para produtos que criem rupturas. Quando uma fórmula de sucesso é encontrada por uma TV comercial, esta acaba por ser seguida pelas concorrentes. Criam-se padrões, em relação à programação televisiva, que acabam por comprometer a recepção de um produto diferenciado.

O caráter central que a telenovela encontrou na programação das TVs não comerciais é exemplar. Os altos índices de audiência conquistados recentemente pela Record, ao angariar criadores da emissora concorrente, nos mostram o peso que o padrão Globo de telenovelas tem no gosto da população brasileira. As novelas atraem anunciantes, modificam os hábitos dos espectadores, alavancam a audiência do restante da programação e acabam por entrar em conflito com uma programação que não esteja nos mesmos moldes. Apesar de ser líder em telenovelas, quando a própria Globo se arrisca em uma minissérie que rompe com a estrutura novelística, muitas vezes, o público cativo da emissora se afugenta, como ocorreu com Os Maias.

A dependência financeira em relação ao Estado, assinalada anteriormente, está longe de trazer conseqüências meramente técnicas para as TVs não comerciais. Na análise que faz de entrevista com Roberto Muylaert, ex-presidente da TV Cultura, Mota (1992: 147) percebe o quão importante era para ele a autonomia e a independência da emissora, mas também as dificuldades enfrentadas para alcançar tal meta. Assim, Muylaert compara a TV Cultura à situação de um jovem que sai de casa para se tornar independente, mas continua dependendo da mesada dos pais. Para a pesquisadora, "a história da TV Cultura é um exemplo de independência 'relativa' em relação ao poder estatal” (ibid.: 148), o que teria dado margem, ao longo da trajetória da emissora, a tentativas de intervenção do Estado, a mais radical delas ocorrida quando o governador José Maria Marins tentou anexá-la ao governo.

Mas não são apenas nos esforços explícitos de intervenção que a presença do Estado se faz presente nas TVs não comerciais. Muylaert relata que o fornecimento de verbas sempre esteve sujeito às relações de simpatia - a questão era se o governador simpatizava ou não com o presidente da Fundação Padre Anchieta (apud Mota, 1992: 149). 
O tipo de problema que foi enfrentado pela TV Cultura não perdeu a atualidade. Com a criação da TV Brasil, tem se discutido intensamente até que ponto o novo canal e seu conselho curador serão realmente independentes do governo federal.

\section{As fragilidades da linguagem e a necessidade de autonomia}

Se a relação das TVs não-comerciais com o contexto nacional parece exigir dela capacidades inesgotáveis no sentido de atrair o público e propiciar educação, informação e entretenimento de qualidade, o modelo empregado pode, em certas ocasiões, se colocar como um entrave para o estabelecimento da relação desejada. Programas que reproduzem a sala de aula tradicional parecem criar um distanciamento entre os interlocutores, ou mesmo fazer um uso limitado das possibilidades da linguagem audiovisual. Além disso, estamos diante de condições de recepção distintas. Enquanto que, em sala de aula, o professor pode ajustar continuamente seu discurso ao repertório dos alunos, um conteúdo transmitido para milhares de espectadores acaba por passar necessariamente por uma padronização, não podendo ser modificado a cada instante.

Outra questão relevante: embora a TV seja um meio audiovisual, algumas vezes o áudio pode imperar, estaríamos assim, usando a designação de Machado, diante de um "rádio visível" (1988: 15). E, se pensarmos na realidade de parte da programação das TVs não-comerciais brasileiras, a idéia de um "rádio visível" parece ser válida, cabendo à imagem um papel coadjuvante, em certas ocasiões, algo que sem dúvida se configura como limitador para um meio que é áudio, mas também vídeo e que parece estar atrelado a um dos principais problemas das TVs não-comerciais brasileiras, já mencionado - a falta de recursos financeiros.

Se a TV de um país deve revelar pelo menos algumas de suas faces, como viver no Brasil e não expressar descontentamento, insatisfação, crítica às instituições e à sociedade? Como não satirizar, debochar, ironizar a realidade que está aí? A sátira mais amena ou mais mordaz apresenta-se nas palavras de um José Simão, ou nas palavras e imagens de Millôr, nas páginas de jornais e revistas, em programas da TV comercial, mas parece ser rara na TV pública brasileira, salvo uma ou outra exceção, como o excelente Provocações, apresentado por Antonio Abujamra. E não é humor uma boa e acessível forma de educar - educar pelo espírito crítico? Como já fazia a BBC, quando introduziu a sátira em sua programação, em 1962, com That Was the Week that Was, conforme nos informam Briggs e Burke (2004: 242). Mas a sátira resvala na política, com freqüência. Deste modo, a independência em relação ao mercado que fazia e cada vez menos faz parte de TVs não-comerciais encontra sua contra-face menos animadora numa menor independência em relação ao poder
Se pensarmos na realidade de parte da programação das TVs não-comerciais brasileiras, a idéia de um "rádio visível" parece ser válida, cabendo à imagem um papel coadjuvante 
político, tornando necessário o desenvolvimento de modelos de gestão autônomos em relação ao Estado. Todavia, não podemos nos esquecer que, no Brasil, mesmo a TV comercial encontra-se bastante atada ao poder político. Basta verificar que muitos dos atuais parlamentares são donos de afiliadas de grandes redes de $\mathrm{TV}$, num ciclo vicioso que só faz crescer a influência política que exercem. Deste modo, os interesses privados de políticos acabam por penetrar tanto na TV comercial, quanto na não comercial.

\section{Conclusão}

O caminho para a TV não comercial no Brasil parece estar na busca por autonomia intelectual, política e administrativa e na tentativa de conciliar qualidade e audiência. Em nossa perspectiva, contudo, o pleno desenvolvimento desta TV, no âmbito educativo e cultural, não pode ser pensado separadamente da qualidade de ensino que existe no país e da oferta de bens culturais. Como se uma coisa puxasse a outra. Se o indivíduo tem acesso a bons livros, se desenvolveu adequadamente sua capacidade de leitura, um programa sobre literatura não lhe trará tédio, caso contrário se verá desmotivado, como tantos alunos que chegam ao ensino superior sem habilidade para perceber as ambigüidades ou o efeito humorístico de um texto.

\section{Referências}

BOURDIEU, Pierre. Sobre a televisão. Rio de Janeiro: Jorge Zahar, 1997. BRIGGS, Asa \& BURKE, Peter. Uma história social da mídia: De Gutenberg à Internet. São Paulo: Jorge Zahar, 2004.

CARVALHO, Carlos Henrique. Os desafios da TV brasileira. In IANNI, Otávio et al. (orgs.). Desafios da comunicação. São Paulo: Vozes, 2000. p.305-311.

LEAL, LAURINDO. Entrevista concedida a Dafne Melo, em 27 mar. 2007. Disponível em www.brasildefato.com.br/v01/agencia/entrevistas.

MACHADO, Arlindo. A arte do vídeo. São Paulo: Brasiliense, 1988.

MOTA, Maria Regina. A TV Pública, a democracia no ar. Dissertação de Mestrado, UFMG, 1992.

ROCCO, Maria Tereza. Entrevista concedida a Ebenezer de Menezes da Agência EducaBrasil, 2000. Disponível em www.educabrasil.com.br. WOLF, Mauro. Teorias da Comunicação. Lisboa: Presença, 1999. 